indedia $\quad \begin{aligned} & \text { InMedia } \\ & \text { The French Journal of Media Studies }\end{aligned}$

3 | 2013

Cinema and Marketing

\title{
Latino images in Austin, Texas
}

\section{Eugenio Del Bosque and Emilie Cheyroux}

\section{(2) OpenEdition \\ Journals}

Electronic version

URL: http://journals.openedition.org/inmedia/580

DOI: 10.4000/inmedia.580

ISSN: 2259-4728

\section{Publisher}

Center for Research on the English-Speaking World (CREW)

\section{Electronic reference}

Eugenio Del Bosque and Emilie Cheyroux, «Latino images in Austin, Texas », InMedia [Online], 3 | 2013, Online since 22 April 2013, connection on 08 September 2020. URL : http://journals.openedition.org/ inmedia/580 ; DOI : https://doi.org/10.4000/inmedia.580

This text was automatically generated on 8 September 2020

(c) InMedia 


\title{
Latino images in Austin, Texas
}

\author{
Eugenio Del Bosque and Emilie Cheyroux
}

\section{AUTHOR'S NOTE}

Interview conducted on April 25, 2012 at the Alamo Drafthouse Cinema in Austin, Texas, during the $15^{\text {th }}$ Cine Las Americas International Film Festival (April 24-29). I would like to thank the staff of Cine Las Americas who welcome me warmly every year, especially Eugenio Del Bosque and Jean Ann Lauer for taking time to answer my questions in spite of their busy schedule, and also for giving me the opportunity to watch the movies they select every year. 
1 This interview with Eugenio Del Bosque, the director of Cine Las Americas, ${ }^{1}$ an international independent Latino film festival which has taken place in Austin, Texas every April since 1998, helps to understand the significance of such festivals in the representation of Latinos, and particularly Mexican-Americans, in the film industry. In spite of the fact that they are the fastest growing population in the United States, ${ }^{2}$ Latinos are still subjected to disparaging stereotypes and a lack of fair representation. Since the 1960s, they have often demonstrated in front of the Hollywood studios because they were seldom portrayed in mainstream movies except as "greasers"3

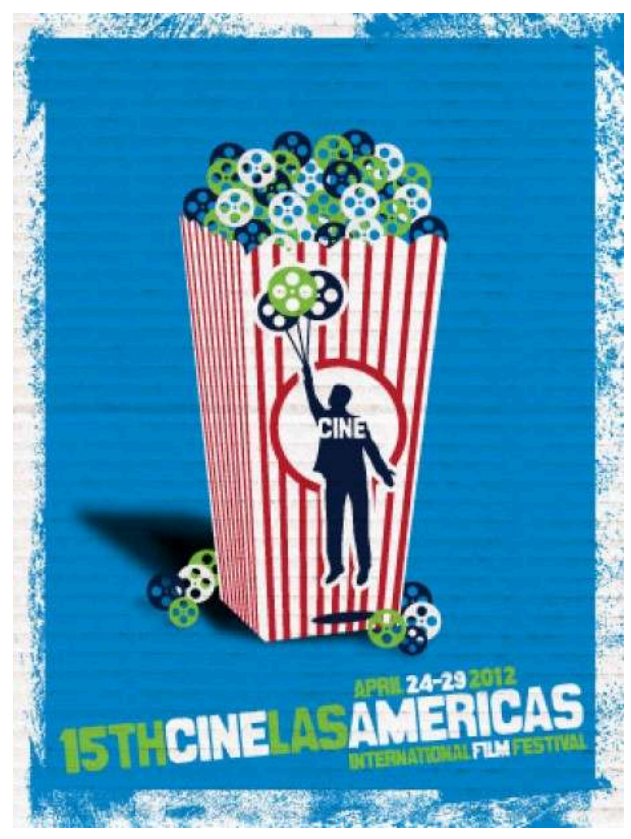
or "fat, slovenly, dark, mustachioed, and often drunken, deceitful and treacherous"

${ }^{4}$ characters. Today, their fight against stereotypes has taken other forms, such as associations ${ }^{5}$, Spanish-language television networks, ${ }^{6}$ and most importantly film festivals - the most famous ones being in New York City, Los Angeles and Chicago. They are thus the most organized minority group and as a consequence, it is interesting to shed light on the evolution and success of Cine Las Americas and its role in challenging and changing mentalities through images by offering a diverse program, both to Latino and non-Latino audiences.

2 The fact that this festival takes place in Austin is no coincidence and shapes its specificity. The city is proud of its reputation for being "different" or "weird", and thus offers diverse screenings to people who are already culturally diverse and culturally well endowed. Austin is a fertile ground for alternative viewpoints, far from Hollywood and its rigid system. This desire to stand out is represented in the name of the festival itself: Cine Las Americas rather than the Austin Latino Film Festival. As for its mission statement, it explicitly states that it is to "promote cross-cultural understanding and growth by educating, entertaining and challenging our community through media". ${ }^{8}$ In its effort to bridge cross-cultural gaps, Cine Las Americas provides English subtitles to every film and shows movies in two different venues: the Mexican American Cultural Center as well as one of the most popular movie theaters in town, the Alamo Drafthouse Cinema. Finally, in order to broaden the audience, the festival team organizes several after-parties in different bars to meet people and encourage them to get involved in screenings organized throughout the year.

3 These unique characteristics are probably the key to the festival's success: while the first years started by screening 20 movies from a couple of countries, in 2012 it featured 101 movies from 23 countries. Among the 12 categories, some of the movies were even presented in other festivals before, showing Cine Las Americas' recognition within the international network of film festivals: for instance, Sleep Dealer (USA/Mexico, 2008) by Alex Rivera premiered at the 2008 Sundance Film Festival, Morir de Pie (Mexico, 2011) by Jacaranda Coffea won Best Mexican Documentary at the Guadalajara International Film 
Festival and Habana Eva (Cuba/Venezuela/France, 2010) by Fina Torres won the Caméra d'Or award at the 1985 Cannes Film Festival. Furthermore, in its commitment to renewing the stock of filmmakers, the festival also shows local movies in the "Hecho en Tejas" ("Made in Texas") category and encourages teenagers to produce their own film for the "Emergencia" program. Local, national and international filmmakers submit over a thousand narrative features, documentaries and short films every year.

Both Del Bosque and his programming associate director Jean Anne Lauer, are dearly committed to the Latino cause but are now feeling the need to focus on quality that goes beyond ethnic categories and proves that Latinos are capable of producing firstrate movies. Two different trends stand out in the festival's program: by showing that Latinos can make entertaining narrative movies that cover a wide range of genres such as comedies, dramas, thrillers, animation and experimental films, Del Bosque and his team want to steer the viewers away from the typical representation of Latinos as "wetbacks" or harmful people crossing the border to corrupt American society. Nevertheless, movies - and especially documentaries - dealing with the border issues are still an important part of the program which reflects the current debate over immigration and the filmmakers' need to give a voice to the people who are directly involved. They almost unanimously portrays the immigrants as dreamers who did not have any other choice than to leave their country to escape poverty, and who are faced with an unfair immigration policy compelling them to take high risks to cross the border.

5 A native of Mexico City, Del Bosque arrived in Texas in 2001 after earning a degree in Communication Sciences from ITESM in Monterrey and working as a writer, producer and editor for independent and documentary film in the United States and in Mexico. In 2005 , he started as a festival volunteer and soon became the executive director. His responsibilities as the head of a 501c3 non-profit association keep increasing but in spite of a few moments of doubts, passion is still driving him to educate audiences and confirm the festival's status as a significant event for Latino filmmaking.

In the following interview, Del Bosque offers insights into the organization and mission of Cine Las Americas, looking back on his seven year involvement.

Why this name, Cine Las Americas?

I do not know who coined the name but it's great. It goes beyond the festival. When we want to do other things the name holds, and then there is the mission statement. We have revised it a couple of times and we sometimes ask ourselves if we need to change it. It's held for fifteen years and it's still good. This is because that language is like the cornerstone of a non-profit organization. And so far, it stands strong. It gives it character and it has great recognition in Latin America. We also didn't want to be the Austin Latino Film Festival. It used to be the Cine Las Americas Festival of New Latin American Cinema. I decided to take the Latino and Latin America out because I didn't want to be perceived as just another Latino film festival... because every city has a Latino Festival. We are the Austin Latino Film Festival and there's nothing wrong with that, but I wanted to be perceived as about the cinema. Yes, it's about Latinos but I just thought there were already too many Latino Film Festivals in the country.

What are the conditions that led to the creation of the festival?

From what I know, it was the brain child of a lady named Lara Coger. She had lived in the Caribbean and she was enamored of the Cuban culture. She had the opportunity of bringing a few Cuban films to Austin and she showed a retrospective of Cuban 
films. Of course, there were a lot of people involved, and from there they got the idea of creating a Latin American film festival. Because of Lara's connections to Cuba, they were attending the Latin American film festival in La Havana in Cuba and they made some connections and got some ideas, and they also decided to schedule the festival in April because [that's when there is]the Chicago Latino Film Festival, which is big. The idea was that they could piggy-back and grab the films which were already in the country. The films could go from Chicago to here because back then, they didn't have the money or the connections. They were just starting.

Then, Lara left at some point, and Sandra Guardado took over. She is still in town and she's an editor. The third lady was Celeste Serna Williams. I don't know who came in and who left, but eventually Celeste was the one carrying on; she established and formed the first board of directors and she made the organization into a $501 \mathrm{c} 3$ nonprofit. By then, it was 2001, it had already existed for five years.

How do you raise money?

The 501 status is a tax-exempt status. You work as a charity organization so people give you money for your programs. A percentage can be deducted from their taxes. The money comes from different parts: first, the city of Austin. There is a program they call cultural contracts; we apply. They have a preference for organizations that show diversity. Historically, that has been one of the main sources of funding for the festival. There's a percentage of their budget that they invest in the arts, and you have to be non-profit. Then, the State of Texas, the Texas commission for the Arts, who has to battle tremendously with the Republican government who wants to shut them down; they almost shut them down last year. Last year, the arts commission of the state of Kansas was dissolved for example. Finally, the National Endowment for the Arts.

We have received money from these three levels: local, state and federal. Then, besides that, there are the corporate sponsors. Austin is the city that has the most non-profit organizations per capita in the country, so there is a lot of competition. Now for us, we are appealing for corporate funding because we have more people. A show like last night ${ }^{9}$ - diverse people and everybody is laughing about the same jokes - for corporate sponsors, that is attractive. So our numbers are showing; we're getting to the point where it becomes something they want to back and we always defend our program. We do want to be in total and absolute control of our program so the sources of money are one thing but it is important to understand that we don't compromise the program for the sake of money.

Then, there are individual donors who are citizens who want to support it; we have a few people who want to support it and give us money every year. We are actually starting a membership program this summer so people can give fifty bucks a year and you get a discount.

What is Cine Las Americas' role as a Latino festival?

One would think that Texas is flat and culturally void but it's not. It's interesting that you probably look at this in the context of the Mexican-American culture here because of course, the first thing that comes to mind about Latinos in Austin and Texas at large is Mexican-Americans, because there's a huge population, but the film festival really could not exist if the diversity was only Mexican-American. It's such a particular culture, and in my experience with the festival, sometimes Mexican- 
Americans don't want to be Mexican and they also don't want to be American. They are in between.

I think it's different for somebody like me who grew up in the middle-class. I know people of the same strata here and we do go back and forth. And we kind of choose to be here. But when people from the countryside have to leave their place of origin in Mexico to come to the U.S., it's kind of more like a forced choice. A lot of times they just don't have any practical reason to return, and from what I see, when a migrant comes and stays and has a family, just trying to be accepted, they lose the Spanish language to connect to the local culture. If there isn't any practical reason to return to Mexico, they don't get their children interested in going back so in one generation, you lose the whole connection and that culturally isolates people. Mexican-American culture is very rich but it's also very isolated.

I have been in Texas for 11 years and I have a child here who is Mexican-American but there is something very important about film and how it relates to audiences. These people are not used to going to the movies; they are not here to be doing that; they're here to work. For the ones who actually end up settling and forming a family or bringing their family from Mexico, they'll probably integrate a little bit more into the cultural offerings of a city but they'll probably go to watch blockbusters, what the children would want to go and see. The fact that Texas is $30 \%$ Latino doesn't necessary mean that the audience for an international Latino festival exists because there's a level of education, there's a level of economic development required for a household or individual to have the time and energy to come and watch a movie. People who work really hard and have two or three jobs because they are immigrants and send money back, they just don't have the time.

Why is the festival organized in two venues? The Mexican American Cultural Center (MACC) and the Alamo. Do you expect more Mexican-Americans at the MACC and a more diverse mix at the Alamo?

We always keep coming back to the MACC, because culturally in Austin, that's where we belong. We belong in the Alamo because of cinema. I think bringing the festival to a cultural center is important because you get in touch with the community. We want to bring them a little bit closer, we want to offer at least something that is free. For us it's being able to get close to the community and share the wealth. A lot of those people may not actually be interested in participating in the festival itself and buying the badge. They just want to go see a movie. And when you have a large population of undocumented immigrant, sometimes they are apprehensive of coming to a public place such as this one, the Alamo where the first thing you do is show an ID because it's possible to buy beer. So we also want to have a place where it's safe like the MACC - tierra franca... it's good for everyone. All they have to do is go and it's fine and you're welcome. No matter the status, because it's very difficult for undocumented people, you have to be under the radar. Coming to places like the Alamo is often feels like you're exposing yourself.

Do you watch and document carefully who attends the festival?

We try to document sometimes through surveys; we try to understand who people are and what level of education they have. I started as a volunteer and I've been the director for six years. Now I know a little bit better who is potentially the audience, so I'm not afraid of showing a completely obscure Argentinian film at 4PM gathering less than fifteen people. That's not a surprise for me. The first time I really saw 
something different was when we showed a retrospective of Mexican horror films and the shows were at 8PM. and they were free - that's the important part - and we got Mexican families, but the real Mexican families. If you would describe them here, a lot of them were very large families and they are with the children.

Latinos are very concerned about stereotypes. Do you carefully choose the movies so that they project a positive image of the community?

I think now we are looking for balance. We will venture to have Dulce Maria in the house - somebody who was in a juvenile music group. I think a few years ago, I would have been like "Never" but we saw the results, there were so many people that had never been to the festival before. So we have matured in that regard, taking into account a wider audience, accepting we don't know it all. There are different things that people like so the selection process also works towards that. We have different personalities watching different films. Person A said that movie is great and person B says that movie sucks and then we watch it and reconcile and understand who the audience is.

Staying away from stereotypes is super-important. For that matter you just buy a ticket to the multiplex and watch whatever movie is showing there. It's funny if you want to go and see Casa de mi padre ${ }^{10}$, that's all good but that's not what our mission is. Latino filmmaking in the U.S. has really matured in the last few years. But I think in the past it used to be a lot more stereotypical. I think actually stereotypes have lost their coolness for the mainstream. We still see it. There are still a bunch of stereotypes and they change.

Being a Latino Festival, you always have to deal with certain issues and historically Latin American film is very politicized; it used to be all about politics. So, for a long time, we were once called a "tear-jerking film festival" because everything was just appalling... migrants dying... That has to do with the selection process but that has also with the culture the filmmakers are trying to represent. Unfortunately, the story of the migrant is still current but I think the way the filmmakers are looking at that story is changing... finally! I'm sure we're still going to see terrible things portrayed but maybe the right questions will start being asked at least...

We want the questions asked; we don't pretend that any movie is going to answer anything. What matters, as part of our mission, is to challenge the audience. There are things that people don't want to talk about and there's something very important for us in the U.S. I think it's changing; everywhere you go they tell you the US is a bubble because they don't want to know about other cultures, they don't want to see subtitled films. I'm probably getting myself in trouble saying this but that's kind of true. What is important about these stories is that a lot of what is happening down South has to do with what is happening here. There's almost always a connection, one way or another. And a lot of times, people don't want to talk about it here, in the media or movies. So, to show it and to show that there is a consciousness about it here is great and fair for the people. Share, communicate it.

What is the role of the parties after the screenings?

The parties are great because people talk about it. That's very interesting because last night, I was talking to a lot of Mexicans, young, who we've never seen before and they were like "really, you've been around for fifteen years?" They were all speaking Spanish. It seems to me they were young people entering the workforce and I told 
them to come back and see something they may not choose at first, give it a shot. With these young Mexicans, that was really interesting last night. With Americans... Austin audiences are great because they are very well educated; they know their films, they will complain if a film is not good. Half of our audience is English-speaking - that's why everything needs to be subtitled - and people have connections, have travelled, may have family in other parts of the world, or they just like the culture so they want to experience it through film, or they're married to a foreigner.

Dulce last night, when she was sitting in the theater, said "So not everybody is Mexican here" and they speak Spanish. She had been to the Los Angeles Film Festival and to San Diego and there were thousands of Mexicans coming to see her. And here, she was scared because her English was not good enough. As long as people understand, it's fine.

The first thing I need to do is get a sense of who is in here. That's why I asked "English or Spanish?" Half the theater said "En español". It's kind of silly that we go back and forth but I do think if there are two Americans who don't speak Spanish, I do want them to come back. I don't want them to think they were just doing their own thing. To make it a better festival, I think we need to have a bilingual website.

How do you want to see the festival evolve?

It's like a person that grows and matures. Now we have a fifteen year old. As we keep evolving and growing older, we have different needs. It all has to do with also maturing the organization. We've been experimenting a few things: my first year as a volunteer in 2005, the festival was ten days long and I don't want to tell you how we felt at the end. It was really really hard. After that, we shortened the festival. When I came in, we made it five days and I organized the program into more or less what it is now in terms of competitive sections. With the idea of creating a truly pan-American experience because it seemed a little hypocritical to create a Latino festival and not take into account the indigenous cultures. Then, I became the director, and we worked with other team members. When Jean came is when I felt we could really be strong in terms of programming. She took what we had and she tightened it up. She added to it and made it work. The Hecho en Tejas had been there and had disappeared because I didn't have the connections to curate it and Jean does. She really made something of it and in general she curated the program into something that was deserving of an international Latino film festival.

But then at this point it's not about making the festival bigger. Austin is not that big of a city. I think what it needs is to grow roots, foundations and establish the festival in a way that we can bring more people, more guests, and we can keep our character: laid-back, relaxed and friendly. Austin is not a place for complicated protocols. It's just relaxed. We want to keep it that way. I was looking at pictures from other festivals while I was trying to find pictures to promote our festival and I couldn't find a picture without a guy wearing shorts. At other festivals, everybody is so dressed up. That's fine but it's just not what happens here.

\section{Are you planning on keeping archives of the movies?}

That's why we're hooked up with the Texas Moving Image. Right now it's only the winners that get their film digitized and archived with them. But in the future, there are things that can be done. It's all about finding a legal framework to be able to do it. But streaming the movies online for a couple of weeks after the festival is an idea. 
They do it here in the cable station. South by Southwest does it, so there are some options. The archive itself is a project of its own. I think we need to find grants and a couple of people cataloguing and doing a database, packaging everything but it's doable. And online, we need to build the archive back to at least have the list of films that have been showed over the years and when the competition started have winners.

Are some filmmakers picked up by bigger film companies after CLA? Does it help them to be more successful?

It's happened before. The first was a horror movie, Room for Tourists in 2005. We had the opportunity to bring people from South America and he sent us his movie. I called him on the phone to ask if he wanted to come by and he was amazed. He was twenty-four. Adrian Garcia. He had started the movie when he was nineteen. We showed it. It didn't win an award because the jury wasn't into horror films but it was a very good horror film. He gave it to somebody else then somebody else and he ended up getting DVD distribution and more investors and now he's all famous in Austin with Fantastic Fest. Yes, things happen. We are not like a big industry festival but things do happen. We try to look for that one thing that is going to flower.

So, in the end, what is the key word?

The key word is diversity.

\section{NOTES}

1. http://www.cinelasamericas.org/

2. According to the Census Bureau, Hispanics accounted for $16.3 \%$ of the population in 2010 with a 43\% increase between 2000 and 2010. Humes, Karen R, Nicholas A. Jones, Roberto R. Ramirez, “Overview of Race and Hispanic Origin: 2010". (PDF). U.S. Census Bureau. March 2011.

3. GÓMEZ, Laura, Manifest destinies: the making of the Mexican-American race, New York: New York University Press, cop. 2007, XII-243 p.

4. LIMÓN, José E., « Tex-Sex-Mex: American Identities, Lone Stars, and the Politics of Racialized Sexuality ", American Literary History, Vol. 9, No. 3 (Autumn, 1997), pp. 598-616.

5. Such as the League of United Latin American Citizens or the National Council of La Raza.

6. Univision or Telemundo.

7. "Keep Austin weird" is the motto of the city and appears on T-shirts and other promotional objects.

8. Jean Anne Lauer. 15th Cine Las Americas' program booklet, p. 2.

9. Alguien ha visto a Lupita? by Gonzalo Justiniano premiered the festival and attracted many people because Dulce Maria is a famous actress and singer in Mexico.

10. This movie was released in May 2012. It stars Will Farrell and Gael García Bernal. 


\section{AUTHORS}

\section{EUGENIO DEL BOSQUE}

Eugenio Del Bosque is the Executive Director of Cine Las Americas, an international film festival which has been taken place in Austin, Texas since 1998. After earning a degree in Communication Sciences in Monterey, Mexico, he came to the United States and started working for the festival.

\section{EMILIE CHEYROUX}

Emilie Cheyroux is a PhD student at the University of Paris 3 Sorbonne Nouvelle. She is currently working on the representation of Mexican-Americans in American movies, focusing on Cine Las Americas International Film Festival as a case study to understand the differences between mainstream and independent films. 